\title{
Nilai PCV dan Diferensial Leukosit Kelinci yang Diinduksi Protein B Spesifik dari Sapi Bunting
}

\author{
(PCV Values and Differential Leucocytes Rabbit induced \\ with Specific Protein B in Pregnant Cow)
}

Widyaningrum Y, Luthfi M

\author{
Loka Penelitian Sapi Potong, Jl. Pahlawan No. 2, Grati, Pasuruan, Jawa Timur \\ drh.yeni@yahoo.com
}

\begin{abstract}
The aims of this study were to determine the effect of specific protein from pregnant cow serum in rabbit (Oryctolagus cunniculus) for value of Packed Cell Volume (PCV) and differential percentage of leucocytes as response to polyclonal antibody production. Rabbits were divided into two groups I (rabbit without the injection) and II (injected with Pregnant Spesific Protein B (PSPB)). Rabbits were injected subcutaneously with $150 \mu \mathrm{g}$ specific protein of pregnant cows with molecular weight 40-60 KDa and CFA adjuvant at weeks 1, 3, and $2^{\text {nd }}$ booster at week eight. Every week after $2^{\text {nd }}$ immunization in five weeks, serum was collected and differential leucocytes and PCV value were counted. The parameters measured were the PCV value and description of differential leucocytes. Data were analyzed by ANOVA, if there is significantly effect, it was followed by $\mathrm{T}$ Test. Results of the examination of PCV in induced rabbits was not significant different with not induced rabbits. In differential leucocyte observation, cell numbers of lymphocytes, eosinophils, neutrofil, basophil group induced by PSPB was significantly different from the group without induction. But, not significantly different to monocyte cell. It can be concluded that the PSPB antigen was able to respond polyclonal antibodies and affect the number of lymphocytes, eosinophils, neutrophils, and basophils $(\mathrm{P}<0.05)$ but not to monocytes and the value of PCV.
\end{abstract}

Key Words: PSPB, PCV Value, Differential Leucocyte, Rabbit, Polyclonal Antibody

\begin{abstract}
ABSTRAK
Penelitian ini bertujuan mengetahui pengaruh induksi protein spesifik dari serum sapi bunting pada kelinci (Oryctolagus cunniculus) terhadap nilai Packed Cell Volume (PCV) dan persentase diferensial leukosit dalam merespon produksi antibodi poliklonal. Kelinci dibagi dalam dua kelompok yaitu kelompok I (kelinci tanpa injeksi) dan II (injeksi Pregnant Spesific Protein B (PSPB)). Kelinci diinjeksi dengan protein spesifik dari sapi bunting dengan berat molekul 40-60 KDa sebanyak $150 \mu \mathrm{g}$ dan adjuvant CFA pada minggu ke-1, 3 dan booster kedua minggu kedelapan secara subcutan. Setiap minggu pasca-imunisasi kedua selama lima minggu dilakukan koleksi serum dan dilakukan penghitungan diferensial leukosit dan nilai packed cell volume (PCV). Parameter yang diukur adalah nilai PCV dan gambaran diferensial leukosit. Data dianalisis dengan ANOVA apabila ada pengaruh nyata dilanjutkan dengan uji T. Hasil pemeriksaan PCV pada kelinci yang diinduksi tidak berbeda nyata dengan kelinci yang tidak diinduksi. Pada pengamatan diferensial leukosit jumlah sel limfosit, eosinofil, neutrofil, basofil pada kelompok induksi PSPB berbeda nyata dengan kelompok yang tidak diinduksi. Namun tidak berbeda nyata terhadap sel monosit. Dapat disimpulkan bahwa antigen PSPB dapat merespons antibodi poliklonal berpengaruh terhadap jumlah sel limfosit, eosinofil, neutrofil dan basofil $(\mathrm{P}<0.05)$ namun tidak terjadi perubahan pada nilai sel monosit serta nilai PCV.
\end{abstract}

Kata Kunci: PSPB, Nilai PCV, Diferensial Leukosit, Kelinci, Antibodi Poliklonal 


\section{PENDAHULUAN}

Strategi Kementerian Pertanian dalam rangka percepatan target pemenuhan populasi sapi potong dalam negeri adalah dengan meluncurkan program upaya khusus sapi induk wajib bunting (UPSUS SIWAB). Program UPSUS SIWAB meliputi dua program utama, yaitu peningkatan populasi melalui Inseminasi Buatan (IB) dan Intensifikasi Kawin Alam (INKA). Program tersebut merupakan upaya pemerintah dalam rangka mewujudkan program swasembada daging sapi dan kerbau yang ditargetkan akan tercapai pada tahun 2026 dengan meningkatkan persentase kebuntingan dan jumlah pedet perkelahiran pada masa produktif sapi potong. Sehingga perlu dilakukan diagnosa kebuntingan awal guna mengurangi hilangnya waktu produksi pada sapi pasca dikawinkan dan membantu efisiensi reproduksi. Diagnosa kebuntingan dini pada ternak sangat penting dalam manajemen reproduksi.

Diagnosa kebuntingan dini akan memberikan informasi keberhasilan perkawinan secara cepat sehingga dapat dilakukan evaluasi dari kegagalan kebuntingan dan meningkatkan efisiensi reproduksi. Diagnosa imunologik merupakan alternatif untuk mendeteksi kebuntingan secara dini, yaitu pada umur di bawah 20 hari setelah perkawinan/ inseminasi, dengan mengidentifikasi substansi yang terbentuk selama masa kebuntingan early pregnancy factor (EPF), yaitu kehadiran protein B spesifik. Widyaningrum et al. (2015) mengidentifikasi protein B spesifik pada sapi bunting pada umur kebuntingan hari ketujuh sebesar 1,5 $\pm 0,2 \mathrm{ng} / \mathrm{ml}$ dan terus ada sampai umur kebuntingan 40 hari sebesar $1,9 \pm 0,2 \mathrm{ng} / \mathrm{ml}$. Protein B spesifik dapat dijadikan imunogen untuk memproduksi antibodi poliklonal. Diperlukan hewan coba yang digunakan untuk memantau respons antibodi selama percobaan dan untuk mendapatkan antibodi. Pada penelitian ini hewan coba yang digunakan adalah kelinci dikarenakan ukuran tubuhnya sesuai, kemudahan mendapatkan darah dan menghasilkan antibodi dengan titer tinggi.

Sel darah putih (leukosit) merupakan unit pertahanan tubuh. Salah satu fungsinya adalah membentuk antibodi (Guyton 1997). Jumlah leukosit di dalam tubuh berfluktuatif dipengaruhi oleh kondisi individu ternak seperti umur, gizi, fisiologis dan stress. Apabila jumlah leukosit tersebut menyimpang dari jumlah normal mempunyai arti klinik penting untuk evaluasi proses pembentukan antibodi. Sistem imun terbagi menjadi dua yaitu sistem imun spesifik meliputi monosit, eosinofil, neutrofil, basofil, sedangkan sel limfosit merupakan sistem imun non spesifik. Sistem imun inilah yang akan berinteraksi terhadap infeksi (Baratawidjaja 2006). Tujuan dari penelitian ini adalah untuk mengetahui pengaruh induksi protein spesifik terhadap diferensial leukosit dan nilai packed cell volume (PCV) pada produksi antibodi poliklonal.

\section{MATERI DAN METODE}

\section{Waktu dan tempat penelitian}

Penelitian ini dilaksanakan selama tiga bulan, pada bulan April-Juni tahun 2016 di Loka Penelitian Sapi Potong.

\section{Materi penelitian}

Materi yang digunakan dalam penelitian ini adalah darah kelinci New Zealand White (Oryctolagus cunniculus) jantan berumur 6-7 bulan sebanyak enam ekor, dibagi dalam dua kelompok yaitu kelompok I (kelinci tanpa injeksi) dan II (injeksi Pregnant Spesific Protein $\mathrm{B} / \mathrm{PSPB}$ ) dari sapi bunting dengan berat molekul 40-60 KDa sebanyak $150 \mu \mathrm{g}$ dan complete freund's adjuvan/CFA). 


\section{Metode penelitian}

Sampel darah diambil dari masing-masing kelinci sebanyak 2-5 $\mathrm{ml}$ melalui vena auricularis. Darah ditampung dalam tabung reaksi anti koagulan Ethylene Diamine Tetra Acetic Acid (EDTA). Darah diambil pada hari ke-0 sebelum penyuntikan (pre-imunisasi) sebagai kontrol, setiap minggu pascaimunisasi kedua selama lima minggu dilakukan pengambilan darah atau koleksi serum. Prosedur isolasi Ig G tertuang pada Tabel 1. Kemudian sampel darah dianalisis diferensial sel darah putih (leukosit) dan PCV.

Tabel 1. Prosedur imunisasi dan isolasi IgG

\begin{tabular}{llc}
\hline Minggu ke- & \multicolumn{1}{c}{ Prosedur } & Adjuvan \\
\hline 1 & Imunisasi 1 bleeding pre-imun & CFA \\
3 & Imunisasi 2 (Booster 1) & IFA \\
4 & Bleeding 1 & - \\
5 & Bleeding 2 & - \\
6 & Bleeding 3 & - \\
7 & Bleeding 4 & - \\
8 & Bleeding 5 & - \\
8 & Imunisasi 3(Booster 2) & IFA \\
9 & Bleeding 6 & - \\
10 & Bleeding 7 & - \\
11 & Bleeding 8 & - \\
12 & Bleeding 9 & - \\
13 & Bleeding 10 & - \\
\hline
\end{tabular}

CFA: Complete freund's adjuvan; IFA: Incomplete freund's adjuvan

\section{Packed cell volume (PCV)}

Tabung yang berisi sampel darah diambil sebanyak 2/3 dari panjang tabung hematokrit yang berukuran $75 \times 1,00 \mathrm{~mm}$. Tabung hematokrit dibersihkan dari sisa-sisa darah sampai bersih dengan memakai kertas tissue lalu sumbat dengan plasticin. Kemudian hematokrit dimasukkan ke centrifuge/haemofuge dengan posisi tabung tertutup dan dihidupkan selama 5-10 menit. Persentase PCV dibaca pada alat penghitung hematokrit.

\section{Cara pembacaan PCV}

Tabung hematokrit diletakkan pada pembaca PCV, posisi tabung antara darah dengan tutup plasticin diletakkan sejajar dengan garis 0 , kemudian permukaan lengkung dari atas plasma darah disejajarkan dengan garis lurus yang ada pada pembaca PCV. Persentase PCV dibaca dan hasil penentuan PCV dinyatakan dalam persen.

\section{Diferensial leukosit}

Pemeriksaan ini dilakukan untuk mengetahui perbedaan bentuk-bentuk sel darah putih yaitu neutrofil, limfosit, eosinofil, monosit dan basofil dengan preparat ulas darah yang diwarnai dengan Giemsa. Sampel darah diteteskan pada gelas objek, kemudian gelas objek 
lainnya ditempatkan pada bagian darah tadi dengan membentuk sudut $30^{\circ}$ dan didorong sepanjang gelas objek sampai terbentuk usapan darah tipis. Ulasan darah dikeringkan di udara, kemudian difiksasi dengan metanol selama lima menit, lalu dimasukkan ke dalam pewarna giemsa $10 \%$ selama 30 menit. Selanjutnya dicuci dengan air mengalir dan dikeringkan di udara. Preparat ulas darah diperiksa di bawah mikroskop dengan pembesaran 1.000 kali untuk pengamatan persentase jumlah diferensial leukosit darah. Pengamatan dilakukan berdasarkan 15 kali lapang pandang.

\section{Parameter yang diukur}

Parameter yang diukur adalah nilai PCV dan gambaran diferensial leukosit.

\section{Analisis data}

Data dianalisis dengan sidik ragam (ANOVA). Apabila terdapat perbedaan antar perlakuan, maka dilanjutkan dengan uji $\mathrm{T}$.

\section{HASIL DAN PEMBAHASAN}

Berdasarkan penghitungan nilai PCV pada kedua kelompok kelinci antara yang diinduksi dengan yang tidak diinduksi, secara statistik tidak ada perbedaan yang signifikan $(\mathrm{P}>0,05)$. Nilai PCV pada kelinci yang tidak diinduksi rata-rata dari minggu ke-1 sampai ke-12 sebesar 34-37\%, sedangkan pada kelinci yang diinjeksi antigen PSPB dari sapi bunting nilai PCV berfluktuasi, nilai PCV menurun pada minggu ke-3 pasca-induksi preimunisasi $28 \%$ kemudian meningkat minggu ke-4 dan mencapai puncaknya pada minggu ke-5, kemudian mulai menurun di minggu ke-9 dan ke-10 pasca-booster 26-29\% (Gambar 1). Rata-rata nilai hematokrit perlakuan non-induksi PSPB lebih stabil, nilai hematokrit merupakan persentase sel darah dibandingkan dengan volume darah keseluruhan. Ini menunjukkan bahwa volume sel darah pada kelinci non-induksi lebih stabil dari minggu ke-1 sampai ke-12 dibandingkan dengan kelompok yang diinduksi PSPB. Menurut Budiyono (2008) nilai PCV normal pada kelinci 33-48\%. Artinya imunisasi dengan antigen berpengaruh terhadap nilai PCV namun tidak berpengaruh signifikan. Kelinci dengan nilai PCV di bawah normal 33\% dimungkinkan mengalami anemia

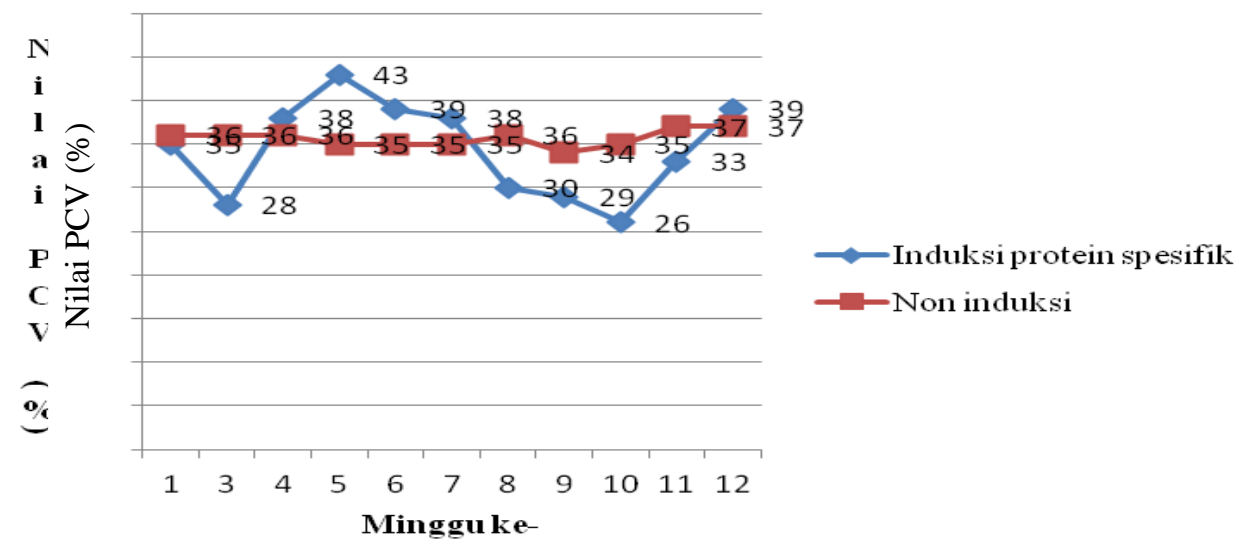

Gambar 1. Nilai packed cell volume pada kelinci induksi dan non-induksi

Hasil pemeriksaan diferensial leukosit pada kelinci New Zealand White ditemukan jumlah limfosit pada saat preimunisasi, pascaimunisasi dan koleksi Ig G tertuang pada 
Tabel 2. Berdasarkan hasil pengamatan pada bleeding preimun minggu pertama jumlah limfosit pada kedua kelompok memiliki persentase limfosit dalam kisaran normal 36,6 $\pm 10,9$ dan 50,0 $\pm 2,8$. Jumlah limfosit normal kelinci adalah 28-85\% (Campbell 2004). Hal ini terjadi karena kelinci diimunisasi 1 bleeding preimun oleh antigen PSPB dari sapi bunting tidak memproduksi antibodi terhadap protein spesifik. Bleeding preimun berfungsi sebagai kontrol yaitu sebagai pembanding nilai absorbansi titer antibodinya dengan bleeding setelah booster pertama dan kedua.

Pada minggu ketiga terjadi peningkatan limfosit pada kelinci pasca-induksi $68,6 \pm 8,5 \%$. Hal ini merupakan respon tubuh terhadap stimulasi dari antigen protein spesifik sedangkan pada kelompok kelinci yang tidak diimunisasi tidak terjadi peningkatan limfosit $30,3 \pm 29,8 \%$. Hasil analisis statistik menunjukkan jumlah sel limfosit pada kelompok induksi PSPB berbeda nyata dengan kelompok yang tidak diinduksi $(\mathrm{P}<0,05)$ pada minggu ketiga. Hal ini mengindikasikan bahwa imunisasi dengan PSPB dari sapi betina bunting berpengaruh terhadap jumlah sel limfosit dalam darah. Sel limfosit merupakan sel-sel yang bertanggung jawab dalam respon antigen-antibodi. Dalam proses tanggap kebal limfosit dibedakan menjadi sel B dan sel T. Sel limfosit akan merespon antigen terhadap pembentukan antibodi yang bersirkulasi di dalam darah atau dalam sistem kekebalan seluler (Frandson 1992). Keberadaan sel B yang mengakibatkan limfosit berperan sebagai sel imun yang tanggap kebal humoral dan selular untuk memproduksi antibodi (Yudha et al. 2014). Protein spesifik yang masuk di dalam tubuh kelinci dianggap sebagai suatu benda asing, sehingga memicu respon imun/merangsang aktivitas sel makrofag merubah antigen menjadi partikel imunogenik sehingga akan merangsang kerja sel B dan sel T (Jain 1993). Di dalam tubuh kelinci terjadi pengikatan protein oleh reseptor ke sel B. Protein diendositosis masuk ke sel dipecah menjadi peptide dan terjadi ikatan sel B dengan reseptor sel T. Terjadi proliferasi sel B menjadi sel B plasma dan sel B memori. Sel B plasma akan menginduksi pembentukan immunoglobulin $G$ yang merupakan antibodi terhadap protein spesifik.

Pada minggu ke-4, 5, 6 dan 7 nilai limfosit kelinci yang diinduksi PSPB berangsurangsur turun $35 \pm 20,80 \%, 56,3 \pm 20,65 \%, 47,0 \pm 23,5 \%$ dan $55,6 \pm 2,3 \%$ ini sesuai dengan titer antibodi tertinggi setelah booster pertama mulai dari bleeding minggu ketiga dan berangsur-angsur turun. Tingginya titer antibodi pada bleeding minggu ketiga dikarenakan kadar antigen dalam tubuh kelinci mencapai titik tertinggi sehingga antibodi dihasilkan dapat mencapai kadar tertinggi. Penurunan nilai limfosit minggu keempat karena konsentrasi antigen yang ada di dalam tubuh kelinci telah menurun sehingga jumlah antibodi yang diproduksi juga mengalami penurunan. Sedangkan persentase sel limfosit

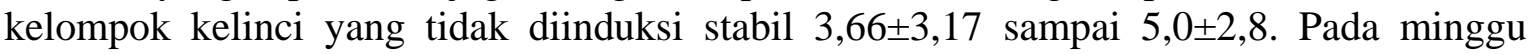
kesembilan sel limfosit kelinci meningkat $66,3 \pm 6,3 \%$. Hal ini dikarenakan pada minggu kedelapan dilakukan booster kedua. Pada saat dilakukan booster sel B memori akan berikatan kembali dengan antigen PSPB, kemudian akan terjadi aktivasi sel B oleh rangsangan sel $T$ helper yang menyebabkan terjadinya peningkatan sensitivitas antigen. Sebelumnya kelinci juga sudah terpapar antigen yang sama sehingga merangsang respon imun sekunder lebih cepat dibandingkan dengan respons primer (Kresno 2001).

Pada minggu ke-10 dan 11 persentase sel limfosit kelinci kedua kelompok perlakuan semakin meningkat 78,0 $\pm 7,5$ dan 75,3 $\pm 2,6$, sedangkan pada minggu ke-12 terjadi limfositosis karena pelepasan epinefrine yang disebabkan oleh stres fisik maupun emosi (Jain 1993). Diduga karena terjadi perubahan cuaca dari musim panas ke musim hujan di akhir penelitian. Kelinci sangat sensitif terhadap perubahan lingkungan terutama cuaca dan cekaman suhu lingkungan dan kelembaban yang tinggi (Smith \& Soesanto 1988).

Persentase eosinofil pada kelompok kelinci induksi PSPB berbeda nyata dengan kelompok yang tidak diinduksi $(\mathrm{P}<0,05)$. Pada kelompok non-induksi dari minggu kesatu 
sampai ke-12 sel eosinofil normal (Tabel 3). Sedangkan pada kelompok kelinci yang diinduksi PSPB mengalami eosinofilia yaitu peningkatan sel eosinofil mulai pada minggu

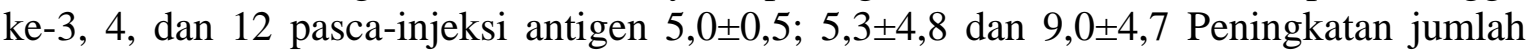
eosinofil merupakan respon dari antigen, fungsi dari sel eosinofil adalah sel fagosit terhadap benda asing yang bereaksi dengan antibodi (Martini et al. 1992). Menurut Frandson (1992) eosinofilia dapat terjadi karena reaksi kompleks antigen antibodi setelah proses imun. Jumlah sel eosinofil normal kelinci 0,5-5\%.

Persentase jumlah neutrofil tertuang pada Gambar 2. Jumlah sel neutrofil normal pada kelinci 30-60\%. Pada kelinci yang diinjeksi PSPB meningkat signifikan $(\mathrm{P}<0,05)$ dibanding kelinci kontrol. Persentase neutrofil meningkat dari awal 5,3\% menjadi 19,6\% setelah diinjeksi dengan antigen PSPB. Pada minggu keempat sampai ketujuh agak lebih kecil hingga 11,3\% dan meningkat lagi minggu kedelapan setelah booster kedua $43 \%$ dan terus menurun sampai minggu ke-12 17,6\% untuk menyingkirkan antigen dari dalam tubuh (Rukayah 2008). Sedangkan pada kelompok kontrol sel neutrofil rata-rata stabil pada minggu pertama 7,3\% menurun terus sampai minggu ke-12.

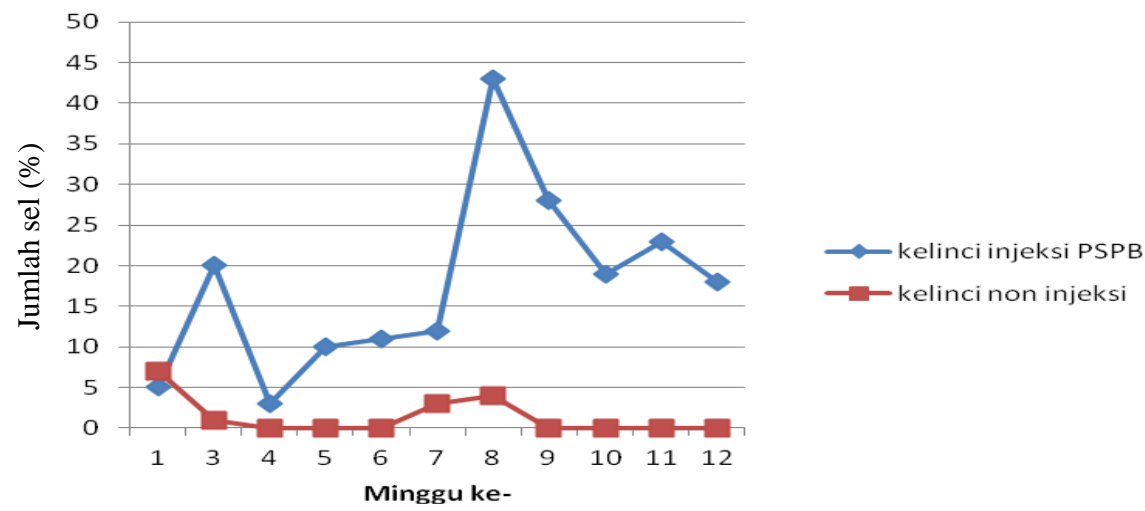

Gambar 2. Jumlah neutrofil pada kedua kelompok kelinci

Berdasarkan pemeriksaan ulas darah sel monosit tertuang pada Tabel 4. Jumlah normal sel monosit kelinci $0-12 \%$, pada kelompok kelinci non-induksi antigen tidak ditemukan sel monosit dari minggu pertama sampai ke-12. Tidak ada perbedaan yang signifikan $(\mathrm{P}>0,05)$ pada kedua kelompok perlakuan. Dalam kelompok I, jumlah monosit bervariasi dari $1,3 \%$ pada awal pre imunisasi menjadi $0,3 \%$ pada hari kesembilan setelah induksi kedua dan terus stabil sampai minggu ke-12. Kondisi ini berarti dalam tubuh kelinci pada kedua perlakuan tidak terjadi infeksi. Peran monosit adalah memfagositosis, kemudian akan berubah menjadi makrofag setelah meninggalkan peredaran darah dan masuk di jaringan. Makrofag mengolah antigen meregulasi imun dan memperbaiki jaringan rusak dengan membuang jaringan yang mati (Tizard 2000).

Pada Tabel 5 menunjukkan bahwa kelinci yang diinduksi antigen mengalami basofilia pada minggu keempat 13,0 $\pm 10,1$ sampai minggu ke-11 21,6 $\pm 18,6$ dan berangsur-angsur menurun. Basofilia merupakan peningkatan jumlah basofil dari nilai basofil normal kelinci $2-7 \%$. Peningkatan sel basofil berbeda nyata dengan kelompok yang tidak diinduksi $(\mathrm{P}<0,05)$. Pada kelinci non induksi tidak ditemukan sel basofil dari minggu pertama sampai minggu kesembilan, kemudian ada di minggu ke-10 sebesar 4,3 $\pm 4,3$ dan menghilang lagi di minggu ke-11 sampai ke-12. Hal ini disebabkan bahwa peran dari sel basofil bertanggungjawab terhadap respon antigen dan alergi dengan jalan mengeluarkan histamin kimia yang menyebabkan peradangan. Namun dalam sirkulasi basofil dapat meningkat sampai 30\% dari jumlah total leukosit tanpa menunjukkan kelainan (Campbell 2004 dalam O’Malley 2005). 
Tabel 2. Jumlah limfosit pada kelompok kelinci yang diinduksi protein spesifik dan kelompok non-induksi

\begin{tabular}{|c|c|c|c|c|c|c|c|c|c|c|c|}
\hline \multirow{2}{*}{ Hewan coba } & \multicolumn{11}{|c|}{ Waktu/minggu } \\
\hline & 1 & 3 & 4 & 5 & 6 & 7 & 8 & 9 & 10 & 11 & 12 \\
\hline Induksi PSPB (\%) & $50,0 \pm 2,8$ & $68,8 \pm 8,5^{\mathrm{a}}$ & $35,0 \pm 20,8$ & $56,3 \pm 20,6$ & $47,0 \pm 23,5$ & $55,6 \pm 2,3$ & $55,3 \pm 10,3$ & $66,3 \pm 6,3$ & $78,0 \pm 7,5$ & $64,6 \pm 4,2$ & $90,3 \pm 6,0$ \\
\hline Non-induksi (\%) & $36,6 \pm 10,9$ & $30,3 \pm 29,8^{b}$ & $3,66 \pm 3,1$ & $6,0 \pm 3,4$ & $3,3 \pm 1,9$ & $5,0 \pm 2,8$ & $3,3 \pm 1,5$ & $2,6 \pm 1,5$ & $39,3 \pm 19,6$ & $75,3 \pm 2,6$ & $87,6 \pm 1,3$ \\
\hline
\end{tabular}

Induksi protein B spesifik pada minggu ketiga dan kedelapan

Tabel 3. Jumlah eosinofil pada kelompok kelinci yang diinduksi PSPB dan kelompok non-induksi

\begin{tabular}{lccccccccccc}
\hline \hline \multirow{2}{*}{ Hewan coba } & \multicolumn{10}{c}{ Waktu/minggu } & \multicolumn{10}{c}{1} \\
\cline { 2 - 11 } & 1 & 3 & 4 & 5 & 6 & 7 & 8 & 9 & 10 & 11 \\
\hline Induksi PSPB (\%) & $2,6 \pm 1,3$ & $5,0 \pm 0,5^{\mathrm{a}}$ & $5,3 \pm 4,8^{\mathrm{a}}$ & $6,6 \pm 3,3$ & $1,0 \pm 1,0$ & $5,0 \pm 2,6$ & $1,0 \pm 0,5$ & $2,3 \pm 1,3$ & $4,3 \pm 2,0$ & $3,3 \pm 1,6$ & $9,0 \pm 4,7^{\mathrm{a}}$ \\
Non-induksi (\%) & $3,0 \pm 0,5$ & $1,3 \pm 1,3^{\mathrm{b}}$ & $0,3 \pm 0,3^{\mathrm{b}}$ & 0 & 0 & 0 & 0 & 0 & $1,3 \pm 1,3$ & $1,6 \pm 1,6$ & $2,6 \pm 2,6^{\mathrm{b}}$ \\
\hline
\end{tabular}

${ }^{\mathrm{a}, \mathrm{b}}$ Superskrips yang berbeda pada kolom yang sama menunjukkan perbedaan nyata $(\mathrm{P}<0,05)$

Tabel 4. Jumlah monosit pada kelompok kelinci yang diinduksi PSPB dan kelompok non-induksi

\begin{tabular}{lcccccccccccc}
\hline \hline \multirow{2}{*}{ Hewan coba } & \multicolumn{10}{c}{ Waktu/minggu } \\
\cline { 2 - 11 } & 1 & 3 & 4 & 5 & 6 & 7 & 8 & 9 & 10 & 11 \\
\hline Induksi PSPB (\%) & $1,3 \pm 0,6$ & $2,6 \pm 1,4$ & $1,0 \pm 0,5$ & $3,3 \pm 2,4$ & $11,3 \pm 7,3$ & $1,6 \pm 1,6$ & $0,3 \pm 0,3$ & $0,3 \pm 0,3$ & $0,3 \pm 0,3$ & $0,3 \pm 0,3$ & $0,3 \pm 0,3$ \\
Non-induksi (\%) & 0 & 0 & 0 & 0 & 0 & 0 & 0 & 0 & 0 & 0 & 0 \\
\hline
\end{tabular}

Tabel 5. Jumlah basofil pada kelompok kelinci yang diinduksi PSPB dan kelompok non-induksi

\begin{tabular}{|c|c|c|c|c|c|c|c|c|c|c|c|}
\hline \multirow{2}{*}{ Hewan coba } & \multicolumn{11}{|c|}{ Waktu/minggu } \\
\hline & 1 & 3 & 4 & 5 & 6 & 7 & 8 & 9 & 10 & 11 & 12 \\
\hline Induksi PSPB (\%) & $0,5 \pm 0,3$ & $4,6 \pm 1,3$ & $13,0 \pm 10,1$ & $34,6 \pm 14,9$ & 0 & $35,6 \pm 25,2$ & $27,0 \pm 24,5$ & $28,0 \pm 24,5$ & $22,3 \pm 21,8^{\mathrm{a}}$ & $21,6 \pm 18,6$ & 0 \\
\hline Non-induksi (\%) & 0 & 0 & 0 & 0 & 0 & 0 & 0 & 0 & $4,3 \pm 4,3^{\mathrm{b}}$ & 0 & 0 \\
\hline
\end{tabular}

${ }^{\text {a,b }}$ Superskrip yang berbeda pada kolom yang sama menunjukkan perbedaan nyata $(\mathrm{P}<0,05)$ 


\section{KESIMPULAN}

Hasil induksi antigen PSPB dari sapi bunting pada hewan coba kelinci dapat merespon imun dalam memproduksi antibodi poliklonal berpengaruh terhadap jumlah sel limfosit, eosinofil, neutrofil, dan basofil namun tidak terjadi perubahan pada nilai sel monosit serta nilai packed cel volume (PCV).

\section{UCAPAN TERIMA KASIH}

Ucapan terimakasih disampaikan kepada Bapak Kepala Loka Penelitian Sapi Potong yang sudah membiayai kegiatan penelitian dalam DIPA tahun anggaran 2016, Drs. Lukman Affandhy S yang telah memberikan saran dan masukan terkait penulisan makalah ini serta Tim Reproduksi yang sudah mendukung kelancaran kegiatan penelitian ini.

\section{DAFTAR PUSTAKA}

Baratawidjaja KG. 2006. Imunologi dasar. Jakarta (Indonesia): Fakultas Kedokteran, Universitas Indonesia.

Budiyono. 2008. Gambaran darah kelinci yang divaksin ekstrak caplak Rhipicephalus sanguineus [Skripsi]. [Bogor (Indonesia)]: Institut Pertanian Bogor.

Campbell NA. 2004. Biologi jilid ketiga. Jakarta (Indonesia): Erlangga.

Frandson RD. 1992. Anatomi dan fisiologi ternak. Edisi keempat. Yogyakarta (Indonesia): Gadjah Mada University Press.

Guyton AC, Hall JE. 1997. Buku ajar fisiologi kedokteran. Edisi kesembilan. Dalam: Setiawan I, Tengadi LMAKA, Santoso A, penerjemah; Setiawan I, editor. Jakarta (Indonesia): Buku Kedokteran EGC.

Jain NC. 1993. Essential of veterinary hematology. Philadelphia (USA): Lea and Febiger.

Kresno SB. 2001. Imunologi: Diagnosis dan prosedur laboratorium. Edisi keempat. Jakarta (Indonesia): Balai Penerbit FKUI.

Martini F, Obar WC, Garrison CW, Wekh K. 1992. Fundamental of anatomy and physiologi. $2^{\text {nd }}$ ed. New Jersey (USA): A Simon and Schucter Company. Englewood Cliffs.

Rukayah T. 2008. Gambaran sel darah putih pada kelinci yang divaksin dengan ekstrak caplak Rhipicephalus sanguineus [Skripsi]. [Bogor (Indonesia)]: Institut Pertanian Bogor.

Smith JBBV, Soesanto M. 1988. Pemeliharaan, pembiakan dan penggunaan hewan percobaan di daerah tropis. Jakarta (Indonesia): UI Press.

O’Maley B. 2005. Clinical anatomy and physiology of exotic species. New York (USA): Elsevier Saunders.

Tizard I. 2000. Veterinary immunology an introduction. $6^{\text {th }}$ ed. Toronto (Canada): WB Saunder Company.

Widyaningrum et al. 2016. Efektivitas protein B spesifik (PSPB) sebagai diagnosis kebuntingan dini pada sapi PO induk. Dalam: Prosiding Seminar Nasional Balai Pengkajian Teknologi Pertanian Lampung. Lampung, 19 Oktober 2016. Lampung (Indonesia): BPTP Lampung.

Yudha F, Eliawardani, Rafina A, Al Azhar, Asmalia N. 2014. Profil darah tikus putih (Rattus norvegicus) yang diinfeksikan Trypanosoma evansi dan diberikan ekstrak kulit batang Jaloh (Salix tetrasperma Roxb). J Kedokteran Hewan 8:164-168. 


\section{DISKUSI}

\section{Pertanyaan}

Mengapa antibodi untuk kelinci hanya menggunakan perlakuan sapi yang bunting?

\section{Jawaban}

Karena tujuan penelitian ingin membuktikan protein pada sapi bunting sebagai indikator deteksi kebuntingan. 